\title{
Zahraei Method for Discovery of New Genes, A Unique Way to Find Ancient Genes and Their Evolution
}

\author{
Shiva Raeisi Dehkordi, Seyed Ali Hossein Zahraei*, Zahra Golafshan, Sepideh Ahmadipour and \\ Melika Rajaei \\ Student research committee, Shiraz University of medical sciences, Shiraz, Iran
}

*Corresponding author: Seyed Ali Hossein Zahraei, Student research committee, Shiraz University of medical sciences, Shiraz, Iran

\begin{tabular}{|c|c|}
\hline ARTICLE INFO & Abstract \\
\hline Received: May 03, 2020 & Citation: Shiva Raeisi D, Seyed Ali Hossein Z, Zahra G, Sepideh A, Melika R. Zahraei \\
\hline Published: 閩 May 12, 2020 & $\begin{array}{l}\text { Method for Discovery of New Genes, A Unique Way to Find Ancient Genes and Their } \\
\text { Evolution. Biomed J Sci \& Tech Res 27(4)-2020. BJSTR. MS.ID.004528. }\end{array}$ \\
\hline
\end{tabular}

\section{Introduction}

Amber is called to the deposit of fossil plant resin and the repository of fossil insects of any age [1] this semi-precious gem that is formed over eons by natural forces out of the resin of trees has been used by humans to prehistoric lifetime, when it was probably considered to have magical powers and was used for trading. Amber amulets and beads dating from 35,000 to 1,800BC have been found, and where they have been found (for example in graves hundreds of miles from their chemically determined origins) has often helped to establish ancient trade routes. The preservative qualities of plant resins were well known by the ancients [2]. Amber is remarkable for its ability to preserve prehistoric, organic material. These inclusions and the successful analysis of their preserved DNA fragments [3].

\section{Method}

By gathering and collecting ancient ambers from different and various sources and origins like Baltic and Myanmar a bank of ancient DNA data will be built. Although researchers usually use big origins for scientific papers the key for success of this method is using small and big origins of ambers so the variety of DNA bank will be wide. Another difference of this method is working on the occupied space around the fossil or insect by amber rather than only the fossil or insect so the probable of discovering new gene mutations increases due to this space may contains ancient microorganisms like bacteria from millions of years ago. At the end this huge data bank of ancient world specially microorganisms should undergo DNA analysis for detecting new gene mutations and discovering new gene sequences.

\section{Conclusion}

As it is obvious collecting of ancient DNA bank from different origins of ambers is helpful and a way for discovering new gene sequences because of probability of mutations during past millions of years and focusing on the around occupied space of amber instead of the insect or fossil is essential specially for who work on microorganisms evolution and genes that are not available nowadays in progressive lifetime and got banned into the amber. The sample size should be repeated from site to site and origin to origin because of microscopic life differences in a small area. Analysing the data gathered by this method will be helpful for new discoveries and answer to unknown questions of evolution during past times so the ambers are bridges to past.

\section{References}

1. Wolfe AP, Tappert R, Muehlenbachs K, Boudreau M, McKellar RC, et al. (2009) A new proposal concerning the botanical origin of Baltic amber. Proceedings of the Royal Society B: Biological Sciences 276(1672): 3403-3412.

2. Poinar GO (1992) Life in amber. Stanford University Press.

3. Grimaldi DA (2203) Amber: window to the past. American Museum of Natural History. 
ISSN: 2574-1241

DOI: 10.26717/BJSTR.2020.27.004528

Seyed Ali Hossein Zahraei. Biomed J Sci \& Tech Res

(C) (i) This work is licensed under Creative

Submission Link: https://biomedres.us/submit-manuscript.php

$\begin{array}{ll}\text { BIOMEDICAL } & \text { Assets of Publishing with us } \\ \text { RESEARCHES } & \text { - Global archiving of articles } \\ \text { - Immediate, unrestricted online access } & \text { - Rigorous Peer Review Process } \\ & \text { - Authors Retain Copyrights } \\ \end{array}$

